\title{
Bioactive Compounds of Softwood Bark as Potential Agents against Human Diseases Include the SARS-CoV-2 Virus
}

\author{
Petra Strizincova $^{1, *(\mathbb{D})}$, Michal Jablonsky ${ }^{1}$ (i) , Marek Lelovský $^{2}$ \\ 1 Institute of Natural and Synthetic Polymers, Department of Wood, Pulp and Paper, Faculty of Chemical and Food \\ Technology, Slovak University of Technology in Bratislava, Radlinského 9, Bratislava SK-812 37, Slovakia; \\ petra.strizincova@stuba.sk (P.S.); michal.jablonsky@stuba.sk (M.J.); \\ 2 Department of Languages, Faculty of Chemical and Food Technology, Slovak University of Technology in Bratislava, \\ Radlinského 9, Bratislava SK-812 37, Slovakia; marek.lelovsky@ stuba.sk (M.L.); \\ * Correspondence: petra.strizincova@stuba.sk (P.S.);
}

Scopus Author ID 57201154453

Received: 24.08.2021; Revised: 2.10.2021; Accepted: 5.10.2021; Published: 24.10.2021

\begin{abstract}
In recent years, significant progress has been achieved in developing natural drugs derived from medicinal plants. Multiple in-vitro screening studies reported that some naturally occurring compounds could possess inhibitory activity against various human viruses. The presented work describes significant biological activities of the main class of secondary metabolites such as phenolic compounds and terpenes located in industrially important tree species Norway spruce (Picea Abies) and Scots pine (Pinus Sylvestris). Phytochemicals show promising in vitro antiviral and cytotoxic activities, making them an attractive starting material for new development in various pharmaceutical products. They have the potential to effectively protect human health against cardiovascular diseases, diabetes mellitus, and as therapeutic agents against the SARS-CoV-2 virus.
\end{abstract}

Keywords: tree bark; phenolic compounds; human diseases; SARS-CoV-2.

(C) 2021 by the authors. This article is an open-access article distributed under the terms and conditions of the Creative Commons Attribution (CC BY) license (https://creativecommons.org/licenses/by/4.0/).

\section{Introduction}

The advantages of wood biomass include its renewability, biodegradability, low cost, easy availability, and rich source of high-value chemical compounds. Presently, the bark of softwood is a low-value by-product in the forest industry. According to the Food and Agriculture Organization of the United Nations, the global annual contribution of tree logs is $3,591,142,000 \mathrm{~m}^{3}$. Thus, the production of tree bark per year is estimated at $359,114,200 \mathrm{~m}^{3}$ [1-3]. Tree biomass represents a valuable raw material to obtain natural, structurally complex, bioactive compounds - extractives. Extractives are natural components of plants composed of a wide range of phytochemicals with diverse chemical structures. They have significant colloidal, chemical, physicochemical, and biological properties. Phytochemicals obtained from plant-based materials have recently been of considerable interest in the scientific sphere. It is due to numerous epidemiological studies indicating their health benefits such as antiviral, antioxidant, cytotoxic, and anti-inflammatory properties [4-6]. The work by Jablonsky et al. [7] summarized the properties of 237 compounds extracted from tree bark. Compounds have been described regarding their biological activities such as cytotoxic (25 identified phytochemicals), antioxidant (26 phytochemicals), antibacterial (42 phytochemicals), anti- 
inflammatory (10 phytochemicals), antimutagenic (5 phytochemicals), pharmacokinetic (5 phytochemicals), and inhibiting (22 phytochemicals).

In the presented work, bark mainly from industrially momentous tree species like Norway spruce (Picea abies) and Scots Pine (Pinus Sylvestris) are described. The focus was on the health benefits of phytochemicals found in extracts isolated from wood biomass. Phytochemicals such as a phenolic compound with capable antioxidant activity and stilbenebased compounds have excellent opportunities for medical applications, including antiviral and antibacterial activities, e.g., phenolic compounds have been shown to protect nerve cells, and stilbene-based compounds such as resveratrol may help prevent the SARS-CoV-2 virus by disrupting the spike protein of the virus.

\section{Materials}

\subsection{Bark compounds.}

The content and spectrum of extractives in tree bark vary depending on the type of tree and can reach up to $40 \%$ of extractives per dry bark. Extractives define a large group of low molecular weight predominantly organic compounds, which form a multicomponent mixture of several chemical groups of substances of lipophilic and hydrophilic character. Lipophilic components include chemical groups such as fatty acids, terpenes (mono-, sesqui-, and triterpenes), and sterols, while the hydrophilic component includes a large group of aromatic phenolic compounds such as flavonoids and tannins. Stilbene glycosides are an interesting group of phenolic compounds found in the bark of Norway spruce (Picea Abies). The specific composition of extractives in a tree is controlled genetically and depends on external conditions such as climatic and soil conditions, location, tree age, tree species, and others $[1,2,8]$. The authors of Ånäs et al. [9] and Krogell et al. [2] indicate a significant difference in the composition between the inner and outer bark of Norway spruce (Picea Abies). The number of lipophilic components in the outer bark of Norway spruce is up to two times higher than the amount present in the inner bark [2]. Table 1 shows a significant difference in the proportion of extractives depending on the tree species for Norway spruce (Picea Abies) and Scots pine (Pinus Sylvestris) in individual parts of the tree. [9].

Table 1. Extractives in different parts of Norway spruce and Scots pine as dry mass percentages.

\begin{tabular}{l|c|c|c|c} 
& $\begin{array}{c}\text { Norway spruce } \\
\text { (Picea Abies) }\end{array}$ & References & $\begin{array}{c}\text { Scots pine } \\
\text { (Pinus Sylvestris) }\end{array}$ & References \\
\hline Bark & $23,5-28,3 \%$ & {$[10],[11]$} & $16-25,9 \%$ & {$[10,12,13]$} \\
\hline Inner Bark & $17,3-38,7 \%$ & {$[10],[12]$} & $15,4-41,9 \%$ & {$[10,12,13]$} \\
\hline Outer Bark & $19,1-43,3 \%$ & {$[10],[11]$} & $16,4-20,8 \%$ & {$[10,12,13]$} \\
\hline Stemwood & $1-4,5 \%$ & {$[13-15]$} & $1-6,8 \%$ & {$[15,17]$} \\
\hline Sapwood & $1,7-2,7 \%$ & {$[17],[18]$} & $3,1 \%$ & {$[16,17]$} \\
\hline Heartwood & $1,1-1,8 \%$ & {$[17],[18]$} & $5,1-5,35 \%$ & {$[17,19]$}
\end{tabular}

\section{Discussion}

\subsection{Extractives as human health protecting agents.}

Clinical studies have shown that phenolic compounds significantly prevent many chronic diseases due to their antioxidant effect [20 - 22]. Several assays assessed antioxidant activity scavenging superoxide and free hydroxyl radicals or determining the DNA strand's oxidative destruction [23]. The antioxidant activity of phenolic compounds is stimulated 
primarily by their reducing properties, and thus they can act as donors of hydrogen atoms and electrons [20]. Beyond antioxidant activity, phenols have been shown to protect nerve cells in vitro by inhibiting the formation of the plaques [24] that characterize Alzheimer's brain pathology. Phenolic compounds can inhibit the growth of several types of microorganisms, including yeasts and bacteria [25,26], and possess gastroprotective, anticarcinogenic, antimicrobial antifungal [27,28], antibacterial, antiseptic [29], hepatoprotective, cardioprotective, antidiabetic effects [30]. The work of Vainio-Kaila et al. [31] confirmed the antibacterial properties of the Scots pine (Pinus Sylvestris) extract against gram-negative Escherichia coli. Gram-positive bacteria Staphylococcus aureus was sensitive to extracts of Norway spruce (Picea Abies) and Scots pine (Pinus Sylvestris). The work corresponds to the results of the work of Ignat et al. [32], where they determined higher amounts of catechin and vanillic acid (71.9 mg / $100 \mathrm{~g}$ dry bark) in ethanolic extract of spruce bark by high-performance liquid chromatography, while gallic acid (10.2 mg / $100 \mathrm{~g}$ dry bark) and quercetin (1.39 mg / $100 \mathrm{~g}$ dry bark) were present in lower concentrations. The results demonstrate the antibacterial effect of the ethanol extract on gram-positive Staphylococcus aureus and gram-negative bacteria such as Pseudomonas aeruginosa and Escherichia coli. Pietarerin et al. [21] demonstrate higher ability to suppress lipid peroxidation from spruce bark extracts (Picea Abies) IC50 = 49 /g / 1 compared to extracts from Jack pine (Pinus banksiana) IC50 = $143 / \mathrm{g} /$ 1 and overhanging Silver birch (Betula pendula) IC50 = 81 $\mu \mathrm{g} / 1$. The bark of Norway spruce contains several stilbene glycosides, lignans, flavonoids, and tannins [33, 34] Stilbene glycosides like piceid (2-[3-Hydroxy-5-[(E)-2-(4-hydroxyphenyl)ethenyl]phenoxy]-6(hydroxymethyl)oxane-3,4,5-triol), isorhapontin (3, 4', 5-trihydroxy-3'-methoxystilbene 3-O- $\beta$ D-glucoside) and astringin (3, 3', 4', 5-tetrahydroxystilbene 3-O- $\beta D$-glucoside), and their corresponding aglycones resveratrol, isorhapontigenin, and piceatannol are the main phenolics present in the wood and bark of Picea species. The work by Jyske et al. [8] estimated the total yields of stilbene glucosides in Norway spruce. A younger tree's bark yielded $27 \mathrm{~g}$ of astringin, $18 \mathrm{~g}$ of isorhapontin, and $5 \mathrm{~g}$ of piceid, while the values for the older trees were significantly higher $618 \mathrm{~g}$ of astringin, $324 \mathrm{~g}$ isorhapontin, and $90 \mathrm{~g}$ of piceid. Resveratrol $\left(3,5,4^{\prime}-\right.$ trihydroxystilbene) is one of the most studied natural products due to its beneficial effects on health. Besides antioxidant effects, anti-aging, anti-cancer, anti-inflammatory, neuroprotective, and cardioprotective effects have been found [35,36]. Resveratrol enhances antibacterial activity against the gram-positive human pathogenic bacteria Bacillus cereus, Staphylococcus aureus, Enterococcis faecalis, and gram-negative bacteria Escherichia coli, Salmonella typhimurium, Arcobacter cryaerophilus [37].

Flavonoids are another important class of phenolic compounds synthesized in trees as bioactive secondary metabolites. They are natural antioxidants capable of quenching hydroxyl and peroxide radicals, having nutraceutical, biological, and clinical effects [38,39]. Flavonoids can be subdivided into different subgroups such as flavanones, flavones, flavonols, flavanols, flavanonols, or catechins, anthocyanins, and chalcones [40]. Of the flavanones, two compounds have been identified in Norway spruce (Picea Abies), namely naringenin and eriodictyol. Naringenin shown in Figure 1 shows strong inhibition against gram-positive bacteria Micrococcus luteus, Staphylococcus aureus, and Staphylococcus epidermidis [41].

Terpenes and terpenoids are divided into mono-terpenes, di-terpenes, sesquiterpenes, and mono-terpenoid, di-terpenoid, sesquiterpenoid, representing a diverse class of extractives in wood biomass. Diterpenoids have antiviral properties against several viruses, such as HIV (Human immunodeficiency virus), hepatitis B virus, dengue fever virus, and herpes simplex 
virus. Chen et al. [42] demonstrated the antiviral effect of the diterpenoid sclareolide. The results of the study indicate broad-spectrum effects on infection caused by filoviruses that cause Ebola viral disease. In addition to the antiviral properties, biological studies have also shown the antifungal, antibacterial, anti-inflammatory, and anti-cancer effects of sclareolide. From diterpenes, $\alpha$ - cadinol was identified in work [43] in spruce bark using supercritical extraction using $\mathrm{CO}_{2}$. $\alpha$ - cadinol is known for its antifungal, hepatoprotective properties with the potential as an effective drug in treating infectious tuberculosis, which in 1900 was one of the three leading causes of death. The triterpenoid gamma-sitosterol also had a high proportion in spruce bark (13.6\% and $13.2 \%)$. In contrast to beta-sitosterol, which is found in almost all plants, laboratory tests in Balamurugan et al. [44] have shown that gamma-sitosterol has the potential as an antidiabetic, reduces hyperglycemia, and can be used in the treatment of type 2 diabetes (Diabetes Mellitus). Gigante et al. [45] studied the biological effects of the effect of dehydroabietic acid and its derivatives on yeasts, filamentous fungi, and bacteria. Resin acids confirmed a bactericidal effect against Staphylococcus aureus and a fungicidal against Trichophyton mentagrophytes.

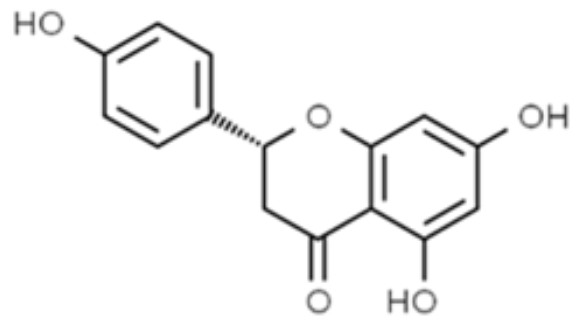

Figure 1. Chemical structure of Naringenin.

Lipophilic compounds such as fatty acids and phytosterols found in conifers reduce the risk of cardiovascular disease. Cardiovascular disease has the highest mortality rate of up to 375,000 people per year in the United States. Research published in the Journal of the American Medical Association has radically changed the understanding of the development of heart disease. The researchers performed a series of nearly 300 autopsies on American victims of the Korean War, with an average age of 22 years. As many as $77 \%$ of soldiers had atherosclerosis, the arteries of some soldiers were blocked up to $90 \%$ [46]. Phytosterols such as campesterol are effective protection against atherosclerosis, stroke, regulate hormonal disorders and hot flashes [47]. Wiliam C. Roberts, editor-in-chief of the American Journal of Cardiology, argues that the main risk factor for arteriosclerotic plaque is cholesterol, especially elevated LDL cholesterol levels [48]. It is the lipophilic extract compounds that have a favorable effect on the level and ratio of LDL and HDL cholesterol. Of the fatty acids [43], linoleic acid, hexadecanoic acid, methyl behenate, and ethyl oleate were identified in the work [42]. Research [49] suggests reducing the risk of lung, prostate, and breast cancer using linoleic acid, which is currently used to treat eczema and diabetic neuropathy.

\subsection{Plant-derived compounds against the SARS-CoV-2 virus.}

Phenolic compounds are a significant group of substances that show strong antiviral activity against the SARS-COV-2 virus, such as quercetin, which also showed antiviral activity in the first type of SARS-CoV PLpro with an IC50 of $8.6 \pm 3.2 \mu \mathrm{M}$ [50]. Scots pine's most common phenolic compounds (Pinus sylvetris) and Norway spruce (Picea Abies) include stilbenes, proanthocyanidins, flavonoids, phenolic acids, and lignans. In common spruce, the main representative of stilbenes is resveratrol, and the main representative of flavanoids is 
myricetin. To a lesser extent, coumaric acid is present in Norway spruce (Picea Abies) and in White fir (Silver Fir Abies) [51]. The most common phenolic compounds of Scots pine ( $P$. sylvestris) include pinosylvin-type stilbenes and flavonol-type and dihydroflavonol-type flavonoids such as quercetin, kaempferol, taxifoline, and their derivatives [52]. Other important phenolic compounds in Scots pine include caffeic, salicylic, ferulic, and gallic acids [53].

The work of Mani et al. [54] classified myricetin, caffeic acid, and quercetin among promising natural compounds that show inhibition of SARS-CoV-2 infection (Figure 2). These extractive compounds have shown a high ability to bind to the angiotensin-converting enzyme 2 (ACE 2), through which the SARS-CoV-2 virus enters human cells [55,56]. Publication by Nguyen et al. [57] confirmed the inhibitory activity of myricetin IC50 $43 \pm 1 \mu \mathrm{M}$, quercetin IC50 $93 \pm 5 \mu \mathrm{M}$, and caffeic acid IC50 $197 \pm 1 \mu \mathrm{M}$ against SARS-CoV-2 M ${ }^{\text {pro }}$.<smiles>O=C(O)/C=C/c1ccc(O)c(O)c1</smiles>

(a) Caffeic acid

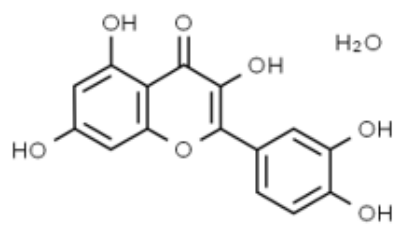

(b) Quercetin

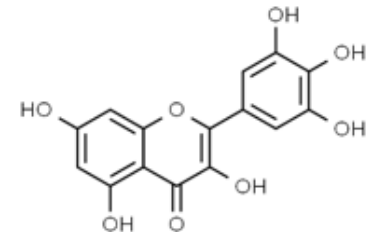

(c) Myricetin

Figure 2. Chemical structure of compounds with antiviral activities.

Several scientific publications [58-61] state that stilbene-based compounds, particularly the chemical compound resveratrol, are a potential natural compound in treating the SARS-CoV-2 virus. In a study by Yang et al. [61], the results showed that resveratrol significantly inhibited the SARS-CoV - 2 virus replication with an $\mathrm{E}_{\mathrm{C}} 50$ (half-maximal effective concentration) of $4.48 \mu \mathrm{M}$. And in the study by Nguyen et al. [57] demonstrated inhibitory activity for resveratrol of IC50 $103 \pm 6$ against SARS-CoV-2 M ${ }^{\text {pro }}$. Savariar et al.[62] identified several compounds, including myricetin gamma sitosterol, as potential phytochemicals capable of inhibiting the SARS-CoV-2 virus major protease 3CLpro (6LU7). In the scientific publication, Fischer et al. [62] identified natural flavonoid compounds, namely (-) - Taxifolin (Figure 3) and rhamnetin, as potential inhibitors of the crystal structure of the main protease the SARS-COV-2 virus.

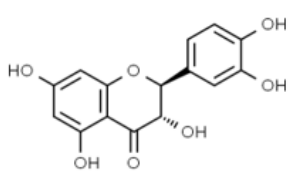

(a) Taxifolin

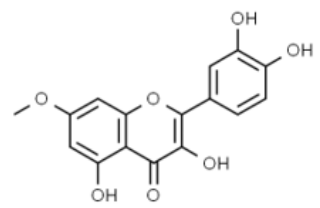

(b) Rhamnetin

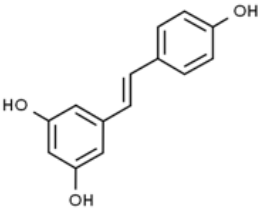

(c) Resveratrol

Figure 3. Chemical structure of Taxifolin, Rhamnetin, and Resveratrol.

Taxifolin (5,7,3,4-flavan-on-ol), also known as dihydroquercetin belongs to the flavonoid subclass of flavanonols. According to scientific studies, it is present in conifers such as Norway spruce, black spruce, Siberian spruce, Roxburg pine, Himalayan cedar, Chinese yew [64]. From a pharmacological point of view, it acts as a chemopreventive agent, inhibits the growth of ovarian cancer cells, has antiproliferative effects on several cancer cells, and can prevent their growth and spreading by inhibiting fatty acid synthase [64]. Taxifolin has also 
shown promising pharmacological effects on microbial infections, oxidative stress, cardiovascular disease, and liver disorders $[65,66]$. It has significant antioxidant activity and has the potential in the food industry to significantly extend the shelf life of foods such as vegetable oils [67,68]. A scientific study by Weng et al. [69] monitored antiviral activity against HCo-V-NL63 coronavirus. Phenolic components such as caffeic acid (IC50 = 3.54 $\mu \mathrm{M})$ and coumaric acid (IC50 $=71.48 \mu \mathrm{M}$ ) showed anti-HCoV-NL63 activity. Caffeic acid significantly inhibited HCoV-NL63 replication independent of the cell type and specifically blocked virus attachment $[69,70]$. In addition, caffeic acid can inhibit other viruses, such as the hepatitis B virus [71].

Infected patients with the SARS-CoV-2 virus show long-term persistent health problems even months after the initial infection. As a result, more than 90 clinical studies have been performed. The effect of commercially available Pycnogenol powder on human immunity support was studied. Pycnogenol is a concentrated natural extract obtained from maritime pine (France). Pycnogenol consists mainly of procyanidins and their monomers such as catechin and epicatechin, as well as phenolic acids. The total amount of procyanidins is $70 \pm 5 \%$. The work of Weichmann et al. [72] demonstrated anti-inflammatory, vascular, and endothelial protective effects of Pycnogenol. Because the SARS-CoV-2 virus strongly affects the lining of endothelial cells, Pycnogenol may be beneficial in promoting recovery and mitigating symptoms due to infection.

\section{Conclusions}

Wood residue-based compounds like stilbene glucoside, terpenes, flavonoids can be used as health-promoting compounds and materials to prevent or treat chronic, cardiovascular, and cancer diseases. Phenolic compounds and terpenes obtained from the bark have potential uses as antiviral agents against diseases such as HIV (Human immunodeficiency virus), hepatitis B virus, dengue fever virus, and herpes simplex virus. Phytochemicals such as quercetin, caffeic acid, or myricetin promise phenolic compounds against the SARS-CoV-2 virus. The bioactive properties of extractives make them attractive materials for the pharmaceutical industry as pharmaceuticals or therapeutic or protective agents. Although the extractives from tree bark show significant biological activity for human health, several in vitro and in vivo studies and further knowledge of the aspects are required.

\section{Funding}

This research was funded by the Operational Program Integrated Infrastructure for the project: "Strategic research in the field of SMART monitoring, treatment and preventive protection against coronavirus (SARS-CoV-2)", Project number 313011ASS8, co-financed by the European Regional Development Fund.

\section{Acknowledgments}

This article was written thanks to the generous support under the Operational Program Integrated Infrastructure for the project: "Strategic research in the field of SMART monitoring, treatment and preventive protection against coronavirus (SARS-CoV-2)", Project no. 313011ASS8, co-financed by the European Regional Development Fund. 


\section{Conflicts of Interest}

The authors declare no conflict of interest. The funders had no role in the study's design, in the collection, analyses, or interpretation of data, in the writing of the manuscript, or in the decision to publish the results.

\section{References}

1. Kain, G.; Barbu, M.C.; Hinterreiter, S.; Richter, K.; Petutschnigg, A. Using bark as a heat insulation material. BioResources 2013, 8, https://doi.org/10.15376/biores.8.3.3718-3731.

2. Krogell, J.; Holmbom, B.; Pranovich, A.; Hemming, J.; Willför, S. Extraction and chemical characterization of Norway spruce inner and outer bark. Nordic Pulp \& Paper Research Journal 2012, 27, 6-17, https://doi.org/10.3183/npprj-2012-27-01-p006-017.

3. Food and Agriculture Organization of the United Nations. Available online: http://www.fao.org/home/en/ (Accessed on 1 June 2021.)

4. Valette, N.; Perrot, T.; Sormani, R.; Gelhaye, E.; Morel-Rouhier, M. Antifungal activities of wood extractives. Fungal Biology Reviews 2017, 31, 113-123, https://doi.org/10.1016/j.fbr.2017.01.002.

5. dos Santos, C.M.; de Souza Mesquita, L.M.; Braga, A.R.C.; de Rosso, V.V. Red Propolis as a Source of Antimicrobial Phytochemicals: Extraction Using High-Performance Alternative Solvents. Frontiers in Microbiology 2021, 12, https://doi.org/10.3389/fmicb.2021.659911.

6. Peng, W.; Li, D.; Zhang, M.; Ge, S.; Mo, B.; Li, S.; Ohkoshi, M. Characteristics of antibacterial molecular activities in poplar wood extractives. Saudi Journal of Biological Sciences 2017, 24, 399-404, https://doi.org/10.1016/j.sjbs.2015.10.026.

7. Jablonsky, M.; Nosalova, J.; Sladkova, A.; Haz, A.; Kreps, F.; Valka, J.; Miertus, S.; Frecer, V.; Ondrejovic, M.; Sima, J.; Surina, I. Valorisation of softwood bark through extraction of utilizable chemicals. A review. Biotechnology Advances 2017, 35, 726-750, https://doi.org/10.1016/j.biotechadv.2017.07.007.

8. Jyske, T.; Laakso, T.; Latva-Mäenpää, H.; Tapanila, T.; Saranpää, P. Yield of stilbene glucosides from the bark of young and old Norway spruce stems. Biomass and Bioenergy 2014, 71, 216-227, https://doi.org/10.1016/j.biombioe.2014.10.005.

9. Anäs, E.; Ekman, R.; Holmbom, B. Composition of Nonpolar Extractives in Bark of Norway Spruce and Scots Pine. Journal of Wood Chemistry and Technology 1983, 3, 119-130, https://doi.org/10.1080/02773818308085155.

10. Nurmi, J. Heating values of mature trees. Acta Forestalia Fennica. 1997, 0 , https://doi.org/10.14214/aff.7517.

11. Rhén, C. Chemical composition and gross calorific value of the above-ground biomass components of young Picea abies. Scandinavian Journal of Forest Research 2004, 19, 72-81, https://doi.org/10.1080/02827580310019185.

12. Voipio, R.; Laakso, T. Chemical composition of the above ground biomass of small sized trees. Pienikokoisten puiden maanpaeaellisen biomassan kemiallinen koostumus. Folia Forestalia (Helsinki);(Finland) 1992, 789, 1-22.

13. Nurmi, J. Heating values of the above ground biomass of small-sized trees. Acta Forestalia Fennica. 1993. https://doi.org/10.14214/aff.7517

14. Kaakinen, S.; Piispanen, R.; Lehto, S.; Metsometsä, J.; Nilsson, U.; Saranpää, P.; Linder, S.; Vapaavuori, E. Growth, wood chemistry, and fibre length of Norway spruce in a long-term nutrient optimization experiment. Canadian Journal of Forest Research 2009, 39, 410-419, https://doi.org/10.1139/X08-180.

15. Holmbom, B. Tall oil precursors of Scots pine and common spruce and their change during sulphate pulping. Åbo Akademi. 1978, 38.

16. Anttonen, S.; Piispanen, R.; Ovaska, J.; Mutikainen, P.; Saranpää, P.; Vapaavuori, E. Effects of defoliation on growth, biomass allocation, and wood properties of Betula pendula clones grown at different nutrient levels. Canadian Journal of Forest Research 2002, 32, 498-508, https://doi.org/10.1139/x01-217.

17. Kilpeläinen, A.; Peltola, H.; Ryyppö, A.; Kellomäki, S. Scots pine responses to elevated temperature and carbon dioxide concentration: growth and wood properties. Tree physiology 2005, 25, 75-83, https://doi.org/10.1093/treephys/25.1.75.

18. Hakkila, P.; Verkasalo, E. Structure and properties of wood and woody biomass. Forest Resources and Sustainable Management Papermaking Science and Technology 2009, 2.

19. Shain, L. The response of sapwood of Norway spruce to infection by Fomes annosus. Phytopathology 1971, 61, 301-307, https://doi.org/10.1094/phyto-61-301.

20. Kähkönen, M.P.; Hopia, A.I.; Vuorela, H.J.; Rauha, J.-P.; Pihlaja, K.; Kujala, T.S.; Heinonen, M. Antioxidant Activity of Plant Extracts Containing Phenolic Compounds. Journal of Agricultural and Food Chemistry 1999, 47, 3954-3962, https://doi.org/10.1021/jf9901461.

21. Pietarinen, S.P.; Willför, S.M.; Ahotupa, M.O.; Hemming, J.E.; Holmbom, B.R. Knotwood and bark extracts: strong antioxidants from waste materials. Journal of Wood Science 2006, 52, 436-444, https://doi.org/10.1007/s10086-005-0780-1. 
22. Willför, S.M.; Ahotupa, M.O.; Hemming, J.E.; Reunanen, M.H.T.; Eklund, P.C.; Sjöholm, R.E.; Eckerman, C.S.E.; Pohjamo, S.P.; Holmbom, B.R. Antioxidant Activity of Knotwood Extractives and Phenolic Compounds of Selected Tree Species. Journal of Agricultural and Food Chemistry 2003, 51, 7600-7606, https://doi.org/10.1021/jf030445h.

23. Legault, J.; Girard-Lalancette, K.; Dufour, D.; Pichette, A. Antioxidant Potential of Bark Extracts from Boreal Forest Conifers. Antioxidants 2013, 2, https://doi.org/10.3390/antiox2030077.

24. Mandel, S.A.; Weinreb, O.; Amit, T.; Youdim, M.B.H. Molecular mechanisms of the neuroprotective/neurorescue action of multi-target green tea polyphenols. 2012, 4, 581-598, https://doi.org/10.2741/s286.

25. Lindberg, L.E.; Willför, S.M.; Holmbom, B.R. Antibacterial effects of knotwood extractives on paper mill bacteria. Journal of Industrial Microbiology and Biotechnology 2004, 31, 137-147, https://doi.org/10.1007/s10295-004-0132-y.

26. Feng, S.; Cheng, S.; Yuan, Z.; Leitch, M.; Xu, C. Valorization of bark for chemicals and materials: A review. Renewable and Sustainable Energy Reviews 2013, 26, 560-578, https://doi.org/10.1016/j.rser.2013.06.024.

27. Veggi, P.C.; Prado, J.M.; Bataglion, G.A.; Eberlin, M.N.; Meireles, M.A.A. Obtaining phenolic compounds from jatoba (Hymenaea courbaril L.) bark by supercritical fluid extraction. The Journal of Supercritical Fluids 2014, 89, 68-77, https://doi.org/10.1016/j.supflu.2014.02.016.

28. Pavlić, B.; Bera, O.; Vidović, S.; Ilić, L.; Zeković, Z. Extraction kinetics and ANN simulation of supercritical fluid extraction of sage herbal dust. The Journal of Supercritical Fluids 2017, 130, 327-336, https://doi.org/10.1016/j.supflu.2017.06.015.

29. Abbasi, H.; Rezaei, K.; Emamdjomeh, Z.; Mousavi, S.M.E. Effect of various extraction conditions on the phenolic contents of pomegranate seed oil. European Journal of Lipid Science and Technology 2008, 110, 435-440, https://doi.org/10.1002/ejlt.200700199.

30. Pereira, P.; Cebola, M.-J.; Oliveira, M.C.; Bernardo-Gil, M.G. Supercritical fluid extraction vs conventional extraction of myrtle leaves and berries: Comparison of antioxidant activity and identification of bioactive compounds. The Journal of Supercritical Fluids 2016, 113, 1-9, https://doi.org/10.1016/j.supflu.2015.09.006.

31. Vainio-Kaila, T.; Rautkari, L.; Nordström, K.; Närhi, M.; Natri, O.; Kairi, M. Effect of extractives and thermal modification on antibacterial properties of Scots pine and Norway spruce. International Wood Products Journal 2013, 4, 248-252, https://doi.org/10.1179/2042645313Y.0000000038.

32. Ignat, I.; Radu, D.; Volf, I.; Andreea, L.P.; Popa, V. Antioxidant and Antibacterial Activities of some Natural Polyphenols. Cellulose Chemistry and Technology 2013, 47, 387-399.

33. Chemspider. Available online: http://www.chemspider.com/ChemicalStructure.388383.html?rid=7d538bac-0dd1-4552-b3be-c355c44d91aa\&page_num=0 (accessed on 1 June 2021).

34. Chemspider. Available online: http://www.chemspider.com/Chemical-Structure.8711.html?rid=dab3111d4d1f-4842-b87c-09b2982d0889\&page_num=0 (accessed on 1 June 2021).

35. Szekeres, T.; Fritzer-Szekeres, M.; Saiko, P.; Jäger, W. Resveratrol and Resveratrol Analogues-StructureActivity Relationship. Pharmaceutical Research 2010, 27, 1042-1048, https://doi.org/10.1007/s11095-0100090-1.

36. Chin-Giaw, L.; Mattheos, A.G.K. Bioavailability and Recent Advances in the Bioactivity of Flavonoid and Stilbene Compounds. Current Organic Chemistry 2010, 14, 1727-1751, https://doi.org/10.2174/138527210792927654.

37. Ma, D.S.L.; Tan, L.T.-H.; Chan, K.-G.; Yap, W.H.; Pusparajah, P.; Chuah, L.-H.; Ming, L.C.; Khan, T.M.; Lee, L.-H.; Goh, B.-H. Resveratrol-Potential Antibacterial Agent against Foodborne Pathogens. Frontiers in Pharmacology 2018, 9, https://doi.org/10.3389/fphar.2018.00102.

38. Liu, C.-M.; Zhao, J.-M.; Li, H.-M.; Song, F.-R. Supercritical Fluid Extraction of Total Flavonoids from Leaves of Acanthopanax Senticosus Harms**Supported by the Natural Science and Technology Foundation of Jilin Province(No. 20020637-1). Chemical Research in Chinese Universities 2007, 23, 233-236, https://doi.org/10.1016/S1005-9040(07)60049-X.

39. Maimoona, A.; Naeem, I.; Saddiqe, Z.; Jameel, K. A review on biological, nutraceutical and clinical aspects of French maritime pine bark extract. Journal of Ethnopharmacology 2011, 133, 261-277, https://doi.org/10.1016/j.jep.2010.10.041.

40. Panche, A.N.; Diwan, A.D.; Chandra, S.R. Flavonoids: an overview. Journal of Nutritional Science 2016, 5 , https://doi.org/10.1017/jns.2016.41.

41. Slimestad, R.; Francis, G.W.; Andersen, Ø.M. Directed search for plant constituents: a case study concerning flavonoids in Norway spruce. Euphytica 1999, 105, 119-123, https://doi.org/10.1023/A:1003473612531.

42. Chen, Q.; Tang, K.; Guo, Y. Discovery of sclareol and sclareolide as filovirus entry inhibitors. Journal of Asian Natural Products Research 2020, 22, 464-473, https://doi.org/10.1080/10286020.2019.1681407.

43. Strizincova, P. Extractive compounds from spruce bark - a source of valuable chemical compounds. Dissertation thesis.Bratislava, 2020. 
44. Balamurugan, R.; Duraipandiyan, V.; Ignacimuthu, S. Antidiabetic activity of $\gamma$-sitosterol isolated from Lippia nodiflora L. in streptozotocin induced diabetic rats. European Journal of Pharmacology 2011, 667, 410-418, https://doi.org/10.1016/j.ejphar.2011.05.025.

45. Gigante, B.; Silva, A.M.; Marcelo-Curto, M.J.; Feio, S.S.; Roseiro, J.; Reis, L.V. Structural Effects on the Bioactivity of Dehydroabietic Acid Derivatives. Planta Med 2002, 68, 680-684, https://doi.org/10.1055/s2002-33788.

46. Enos, W.F.; Holmes, R.H.; Beyer, J. Coronary Disease Among United States Soldiers Killed In Action In Korea: Preliminary Report. Journal of the American Medical Association 1953, 152, 1090-1093, https://doi.org/10.1001/jama.1953.03690120006002.

47. Silbernagel, G.; Genser, B.; Nestel, P.; März, W. Plant sterols and atherosclerosis. Current Opinion in Lipidology 2013, 24, https://doi.org/10.1097/MOL.0b013e32835b6271.

48. Benjamin, M.M.; Roberts, W.C. Facts and Principles Learned at the 39th Annual Williamsburg Conference on Heart Disease. Baylor University Medical Center Proceedings 2013, 26, 124-136, https://doi.org/10.1080/08998280.2013.11928935.

49. Pariza, M.W.; Park, Y.; Cook, M.E. Conjugated linoleic acid and the control of cancer and obesity. Toxicological Sciences 1999, 52, 107-110, https://doi.org/10.1093/toxsci/52.suppl_1.107.

50. Park, J.-Y.; Yuk, H.J.; Ryu, H.W.; Lim, S.H.; Kim, K.S.; Park, K.H.; Ryu, Y.B.; Lee, W.S. Evaluation of polyphenols from Broussonetia papyrifera as coronavirus protease inhibitors. Journal of Enzyme Inhibition and Medicinal Chemistry 2017, 32, 504-512, https://doi.org/10.1080/14756366.2016.1265519.

51. Salguero, G.C. Hplc Analysis of Phenolic Compounds in Norway Spruce With Photodiode Array and Mass Spectrometric Detection. The Science for Population Protection 2014, 2.

52. Metsämuuronen, S.; Sirén, H. Bioactive phenolic compounds, metabolism and properties: a review on valuable chemical compounds in Scots pine and Norway spruce. Phytochemistry Reviews 2019, 18, 623-664, https://doi.org/10.1007/s11101-019-09630-2.

53. Szwajkowska-Michałek, L.; Przybylska-Balcerek, A.; Rogoziński, T.; Stuper-Szablewska, K. Phenolic Compounds in Trees and Shrubs of Central Europe. Applied Sciences 2020, 10, https://doi.org/10.3390/app10196907.

54. Mani, J.S.; Johnson, J.B.; Steel, J.C.; Broszczak, D.A.; Neilsen, P.M.; Walsh, K.B.; Naiker, M. Natural product-derived phytochemicals as potential agents against coronaviruses: A review. Virus Research 2020, 284, https://doi.org/10.1016/j.virusres.2020.197989.

55. Adhikari, S.P.; Meng, S.; Wu, Y.-J.; Mao, Y.-P.; Ye, R.-X.; Wang, Q.-Z.; Sun, C.; Sylvia, S.; Rozelle, S.; Raat, H.; Zhou, H. Epidemiology, causes, clinical manifestation and diagnosis, prevention and control of coronavirus disease (COVID-19) during the early outbreak period: a scoping review. Infectious Diseases of Poverty 2020, 9, https://doi.org/10.1186/s40249-020-00646-X.

56. Wan, Y.; Shang, J.; Graham, R.; Baric Ralph, S.; Li, F.; Gallagher, T. Receptor Recognition by the Novel Coronavirus from Wuhan: an Analysis Based on Decade-Long Structural Studies of SARS Coronavirus. Journal of Virology 2020, 94, e00127-00120, https://doi.org/10.1128/jvi.00127-20.

57. Nguyen, T.T.; Jung, J.-H.; Kim, M.-K.; Lim, S.; Choi, J.-M.; Chung, B.; Kim, D.-W.; Kim, D. The Inhibitory Effects of Plant Derivate Polyphenols on the Main Protease of SARS Coronavirus 2 and Their StructureActivity Relationship. Molecules 2021, 26, https://doi.org/10.3390/molecules26071924.

58. Ramdani, L.H.; Bachari, K. Potential therapeutic effects of Resveratrol against SARS-CoV-2. Acta virologica 2020, 64, https://doi.org/10.4149/av_2020_309.

59. Hoang, T. An approach of fatty acids and resveratrol in the prevention of COVID-19 severity. Phytotherapy Research 2021, 35, 2269-2273, https://doi.org/10.1002/ptr.6956.

60. Filardo, S.; Di Pietro, M.; Mastromarino, P.; Sessa, R. Therapeutic potential of resveratrol against emerging respiratory viral infections. Pharmacology \& Therapeutics 2020, 214, https://doi.org/10.1016/j.pharmthera.2020.107613.

61. Yang, M.; Wei, J.; Huang, T.; Lei, L.; Shen, C.; Lai, J.; Yang, M.; Liu, L.; Yang, Y.; Liu, G.; Liu, Y. Resveratrol inhibits the replication of severe acute respiratory syndrome coronavirus 2 (SARS-CoV-2) in cultured Vero cells. Phytotherapy Research 2021, 35, 1127-1129, https://doi.org/10.1002/ptr.6916.

62. Vincent, S.; Arokiyaraj, S.; Saravanan, M.; Dhanraj, M. Molecular Docking Studies on the Anti-viral Effects of Compounds From Kabasura Kudineer on SARS-CoV-2 3CLpro. Frontiers in Molecular Biosciences 2020, 7, https://doi.org/10.3389/fmolb.2020.613401.

63. Fischer, A.; Sellner, M.; Neranjan, S.; Smieško, M.; Lill, M.A. Potential Inhibitors for Novel Coronavirus Protease Identified by Virtual Screening of 606 Million Compounds. International Journal of Molecular Sciences 2020, 21, https://doi.org/10.3390/ijms21103626.

64. Lee, S.B.; Cha, K.H.; Selenge, D.; Solongo, A.; Nho, C.W. The Chemopreventive Effect of Taxifolin Is Exerted through ARE-Dependent Gene Regulation. Biological and Pharmaceutical Bulletin 2007, 30, 10741079, https://doi.org/10.1248/bpb.30.1074.

65. Bernatova, I.; Liskova, S. Mechanisms Modified by (-)-Epicatechin and Taxifolin Relevant for the Treatment of Hypertension and Viral Infection: Knowledge from Preclinical Studies. Antioxidants 2021, 10, https://doi.org/10.3390/antiox10030467. 
66. Adhikari, B.; Marasini, B.P.; Rayamajhee, B.; Bhattarai, B.R.; Lamichhane, G.; Khadayat, K.; Adhikari, A.; Khanal, S.; Parajuli, N. Potential roles of medicinal plants for the treatment of viral diseases focusing on COVID-19: A review. Phytotherapy Research 2021, 35, 1298-1312, https://doi.org/10.1002/ptr.6893.

67. Sunil, C.; Xu, B. An insight into the health-promoting effects of taxifolin (dihydroquercetin). Phytochemistry 2019, 166, https://doi.org/10.1016/j.phytochem.2019.112066.

68. Si ,C.L. Antioxidant Activities of the Extractives of Larix kaempferi Carr. Fresh Needles. 林產化學與工業. 2007, 27, 21-24.

69. Weng, J.-R.; Lin, C.-S.; Lai, H.-C.; Lin, Y.-P.; Wang, C.-Y.; Tsai, Y.-C.; Wu, K.-C.; Huang, S.-H.; Lin, C.W. Antiviral activity of Sambucus FormosanaNakai ethanol extract and related phenolic acid constituents against human coronavirus NL63. Virus Research 2019, 273, https://doi.org/10.1016/j.virusres.2019.197767.

70. Koutaniemi, S.; Warinowski, T.; Kärkönen, A.; Alatalo, E.; Fossdal, C.G.; Saranpää, P.; Laakso, T.; Fagerstedt, K.V.; Simola, L.K.; Paulin, L.; Rudd, S.; Teeri, T.H. Expression profiling of the lignin biosynthetic pathway in Norway spruce using EST sequencing and real-time RT-PCR. Plant Molecular Biology 2007, 65, 311-328, https://doi.org/10.1007/s11103-007-9220-5.

71. Wang, S.Q.; Du, Q.S.; Zhao, K.; Li, A.X.; Wei, D.Q.; Chou, K.C. Virtual screening for finding natural inhibitor against cathepsin-L for SARS therapy. Amino acids 2007, 33, 129-135, https://doi.org/10.1007/s00726-006-0403-1.

72. Weichmann, F.; Rohdewald, P. Projected supportive effects of Pycnogenol $\mathbb{R}$ in patients suffering from multidimensional health impairments after a SARS-CoV2 infection. International Journal of Antimicrobial Agents 2020, 56, https://doi.org/10.1016/j.ijantimicag.2020.106191. 